\title{
Medicated Liquid Soap Dosage Form
}

National Cancer Institute

\section{Source}

National Cancer Institute. Medicated Liquid Soap Dosage Form. NCI Thesaurus. Code C91145.

A liquid composed of active and inert ing redient(s) in an anionic surfactant, for cleansing. 